\title{
Radioelement geochemistry of alkali granites of the Kerala region, south-west India
}

\author{
M SANTOSH and K VIJAYA KUMAR \\ Centre for Earth Science Studies, P. B. 2235, Sasthamangalam, Trivandrum 695010, India \\ MS received 7 July 1984 ; revised 30 September 1985 \\ Abstract. Th, $U$ and $\mathbf{K}$ abundances in four alkali granites of the Kerala region, south-west \\ India, are presented. The plutons show high radioelement levels, correlatable with those of \\ alkali granites in other regions. The nature of variation is consistent with the correlation of Th \\ and $U$ with accessory phases like sphene, zircon, allanite, apatite and monazite. $A$ \\ geochronologic correlation is also observed between the alkali granites and the Th-bearing \\ beach placers of the region. The petrogenetic features of the alkali plutons, their taphrogenic \\ association, Pan-African affiliation and high $\mathrm{Th} / \mathrm{U}$ levels suggest that the alkali plutons are \\ favourable locales for radioelement exploration.
}

Keywords. Radioelement geochemistry; alkali granites; geochronologic correlation; radioelement exploration.

\section{Introduction}

The Kerala region forms a significant portion of the Indian shield and the southwestern part of the continental margin. The region comprises largely Precambrian crystallines including charnockites, khondalites and migmatitic gneisses. Recent studies reveal the occurrences of a number of granite and syenite intrusives representing a Late Precambrian-Early Paleozoic magmatic regime (Santosh and Nair 1983a; Santosh and Thara 1985; Nair and Santosh 1984). The spatial relationship of the intrusives with regional fault-lineaments suggests a taphrogenic association (Santosh and Nair 1983b; Nair et al 1983). Among the intrusives are a group of granites which show alkaline character and unique petrochemical features (see for example, Nair and Santosh 1984). Even though general geochemical studies of these alkali granites have been attempted, their radioelement abundance has not been reported.

The present paper documents the abundances of $T h, U$ and $K$ in the alkali granites.

\section{The alkali granites}

The alkali granites of the region are represented by E-W elongated plutons near Chengannoor in Alleppey, Ambalavayal in Wynad, Munnar in Kottayam and Peralimala in Cannanore districts. These intrusives are spatially related to major faultlineaments of the region (figure 1). All of them are emplaced within Precambrian basement rocks (figure 2), with which they maintain sharp contacts. Each pluton is exposed over an area of $25-50 \mathrm{~km}^{2}$. Their general geologic characters, including age, are summarised in table 1.

All are massive, pink, medium to coarse grained rocks composed of interlocking 


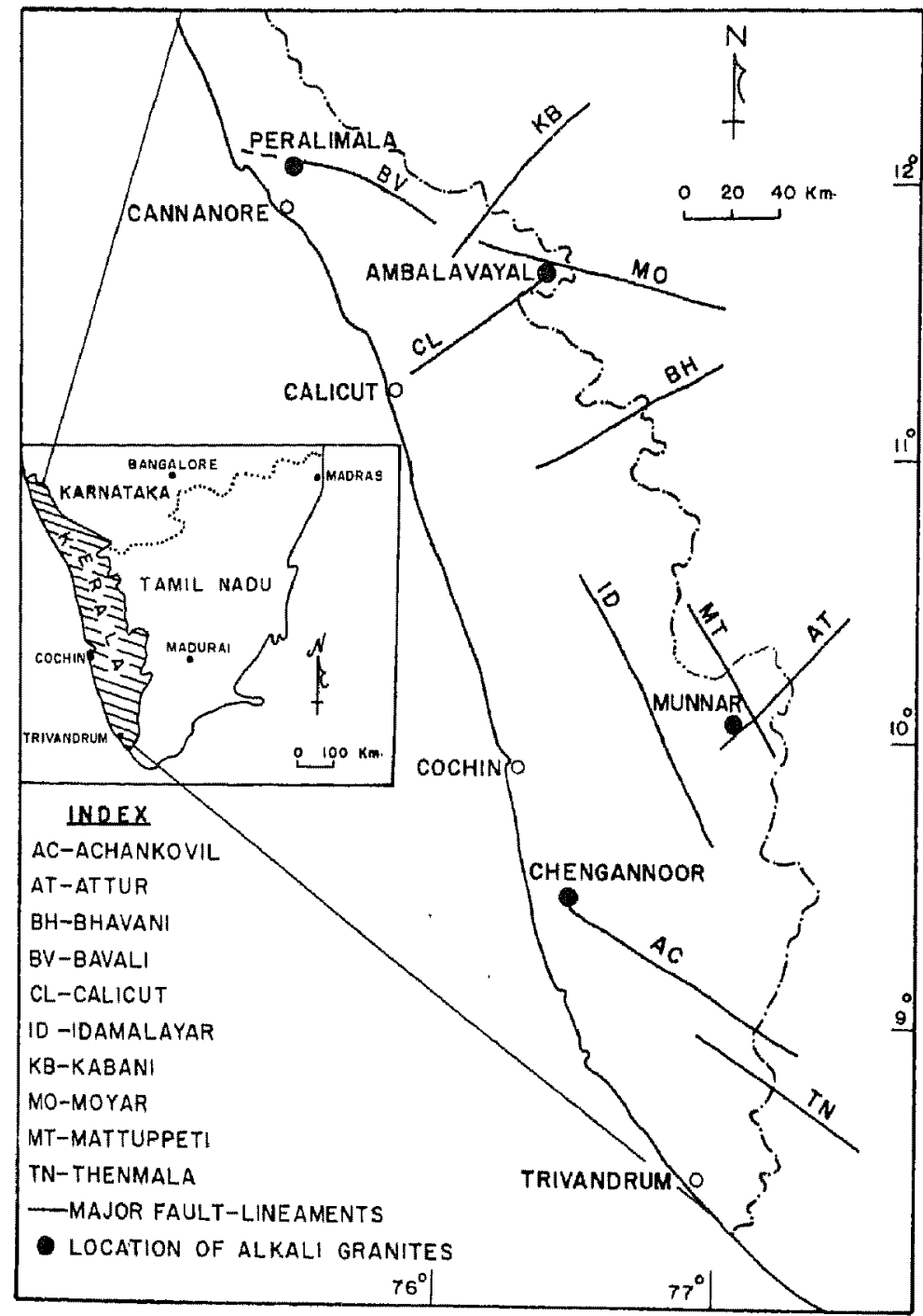

Figure 1. Lineament map of the Kerala region showing the location of the alkali granites.

quartz and feldspar. In thin sections, they show a general hypidiomorphic granular texture with alkali feldspar as the dominant constituent. The perthitic phase in the Kfeldspar grains range from micro and string perthite in Ambalavayal, Munnar and Peralimala to coarse mesoperthite in Chengannoor. Plagioclase is subordinate and shows a range in composition of $A_{b_{95}} A_{5}$ in Ambalavayal to $A b_{85} A n_{15}$ in Chengannoor. It generally occurs as minor laths showing lamellar twinning. Twofeldspar geothermometry based on the Ab-component in coexisting alkali feldsparplagioclase pairs give an estimate of $704-740^{\circ} \mathrm{C}$ for the Ambalavayal granite (Santosh $1985 a)$. The modal $Q-A-P$ proportions of the granite correspond to a range between quartz alkali feldspar granite and normal granite as per Streckeisen's scheme (1976). The major mafic mineral in all the granites, except Munnar, is greenish pleochroic 


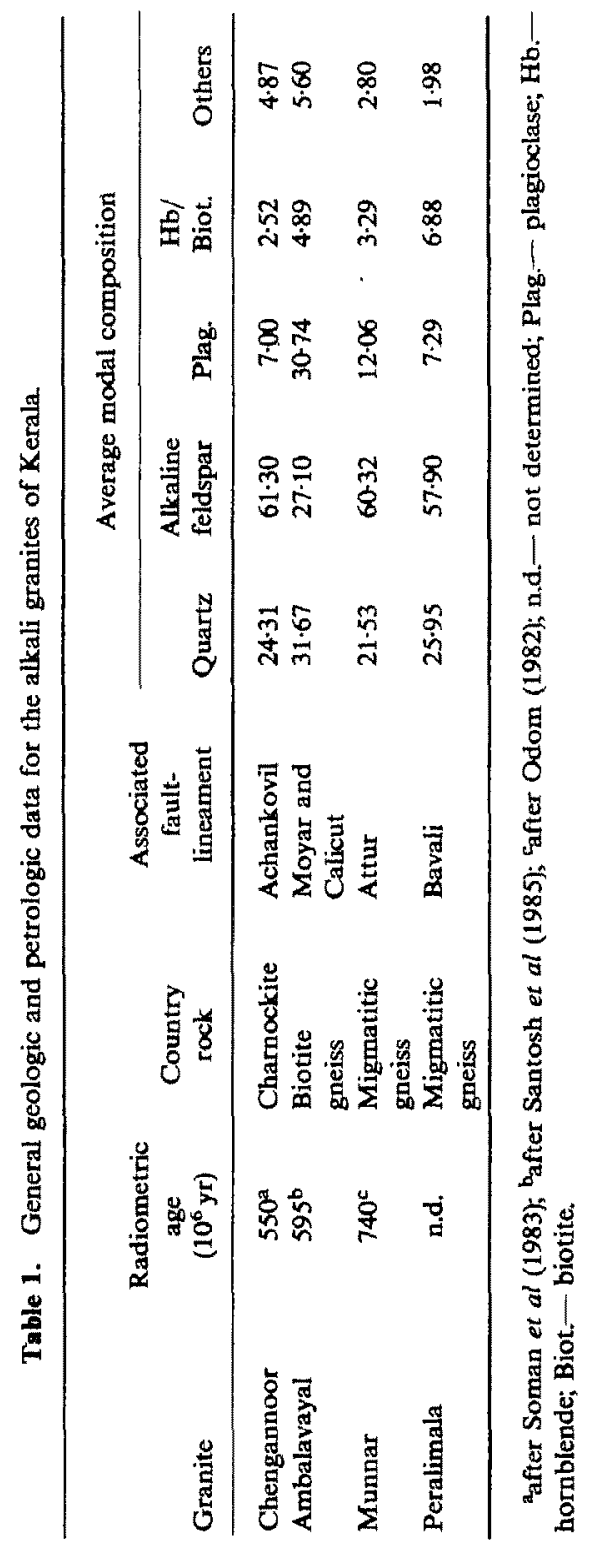




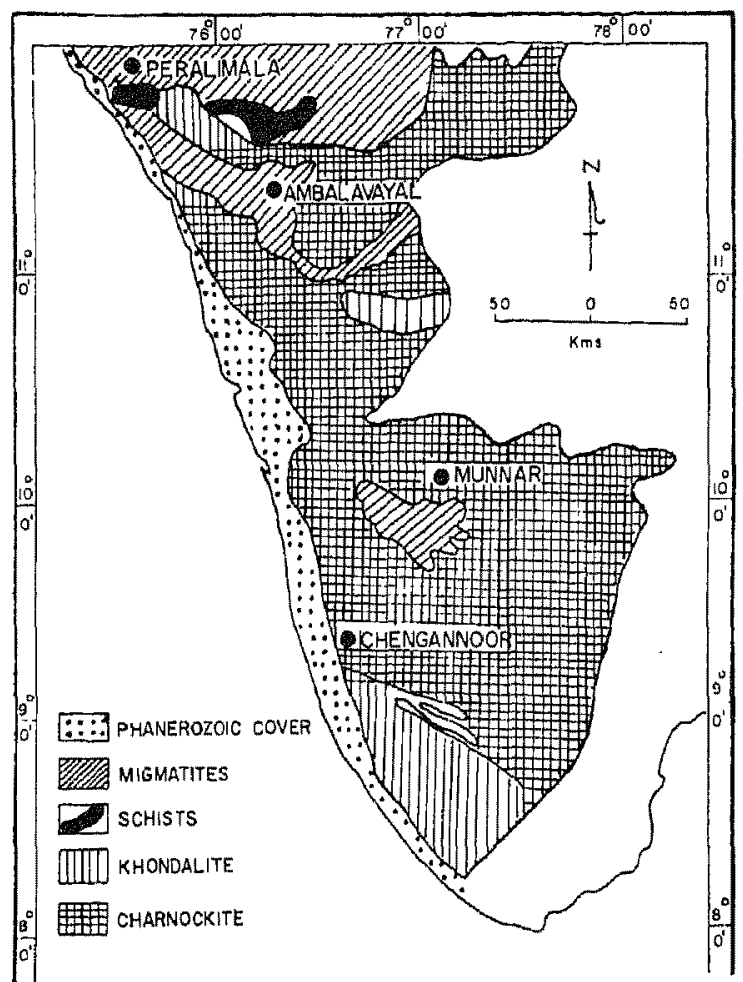

Figure 2. Generalised geological map of the Kerala region showing the location of the alkali granites.

hornblende. In Munnar, biotite forms the dominant mafic constituent, whereas biotite is found in subordinate amounts in the others. Sphene and apatite are ubiquitous accessories in all the granites. Other accessories include zircon, epidote, allanite, calcite and $\mathrm{Fe}$-Ti oxides, Euhedral grains of monazite occur as minor inclusions in biotite and

Table 2. Average major element contents of the alkali granites.

\begin{tabular}{lcccc}
\hline Oxide & Chengannoor & Ambalavayal & Munnar & Peralimala \\
\hline $\mathrm{SiO}_{2}$ & 69.39 & 74.51 & 71.74 & 64.53 \\
$\mathrm{Al}_{2} \mathrm{O}_{3}$ & 15.65 & 13.67 & 13.84 & 18.0 \\
$\mathrm{TiO}_{2}$ & 0.38 & 0.16 & 0.24 & 0.08 \\
$\mathrm{Fe}_{2} \mathrm{O}_{3}$ & 2.68 & 0.94 & 1.68 & 0.93 \\
$\mathrm{FeO}$ & 1.05 & 1.87 & 0.84 & 0.65 \\
$\mathrm{MnO}$ & 0.03 & 0.02 & 0.02 & 0.05 \\
$\mathrm{MgO}$ & 1.62 & 0.42 & 0.66 & 0.62 \\
$\mathrm{CaO}$ & 0.53 & 1.44 & 1.70 & 1.48 \\
$\mathrm{Na}_{2} \mathrm{O}$ & 3.48 & 3.01 & 2.56 & 3.11 \\
$\mathrm{~K}_{2} \mathrm{O}$ & 4.19 & 3.64 & 5.66 & 9.68 \\
$\mathrm{P}_{2} \mathrm{O}_{5}$ & 0.08 & 0.01 & 0.02 & 0.05 \\
\hline
\end{tabular}

Data sources: Chengannoor, after Santosh and Nair (1983a) Ambalavayal, after Nair et al (1982); Munnar, after Nair et al (1983) and Peralimala, after Nair and Santosh (1984). 
hornblende. Such inclusions are especially common in Chengannoor and Ambalavayal granites. Zircon, monazite and allanite grains frequently exhibit metamict texture.

The average major element compositions of the alkali granites are given in table 2 . Moderate variation in $\mathrm{SiO}_{2}$ and $\mathrm{Al}_{2} \mathrm{O}_{3}$ levels, sympathetic variation of alkalies and alumina, higher alkali content and pronounced depletion of $\mathrm{FeO}^{\prime}, \mathrm{MgO}, \mathrm{TiO}_{2}$ and $\mathrm{P}_{2} \mathrm{O}_{5}$ with increasing differentiation are typical geochemical characters of these alkali granites. In the $\log _{10} \mathrm{~K}_{2} \mathrm{O} / \mathrm{MgO}$ vs. $\mathrm{SiO}_{2}$ diagram (Rogers and Greenberg 1981), the plots of the granites fall mainly in the field delineated for alkali granites. Petrochemical features suggest that the alkali granites were derived from partial melts generated at mantle depths as a probable response to crustal distension and mantle degassing prior to the rifting of the continent (Santosh and Nair 1983b; Nair and Santosh 1984).

\section{Abundance of $\mathrm{Th}, \mathrm{U}$ and $\mathrm{K}$}

Fresh representative samples of the alkali granites were collected, mainly from working quarries. Seven samples from Chengannoor, ten from Ambalavayal, five from Munnar and twelve from Peralimala were selected for the present study. The samples were crushed and pulverized to -200 ASTM mesh and were analysed for equivalent $U$ and Th using a ECIL single channel analyser (sC $604 \mathrm{~B}$ ) coupled to a NaI (T1) detector and calibrated using natural standards. $\mathrm{K}$ was analysed by flame photometry.

The analytical results are given in table 3, along with $\mathrm{Th} / \mathrm{U}$ ratios, $\mathrm{Mg} / \mathrm{Mg}+\mathrm{Fe}^{t}$ levels, $\mathrm{SiO}_{2}$ values and mean and standard deviation for each pluton. Th, $\mathrm{U}$ and $\mathrm{Th} / \mathrm{U}$ levels of the alkali granites are compared with those of similar granites from other regions in table 4.

\subsection{Thorium}

The mean thorium values of Chengannoor $(41.4 \mathrm{ppm})$, Ambalavayal $(21.6 \mathrm{ppm})$ and Munnar $(23.8 \mathrm{ppm})$ are considerably higher than the average for granites $(18 \mathrm{ppm}$; Rogers and Adams 1969). However, they are closely comparable with the generally high Th values exhibited by alkali granites of other regions as compiled in table 4 . Rogers $e t$ al (1978) observe that Pan-African granites are Th-rich. In this regard, it is significant to mention that the beach placers in the western coastal tract of Kerala are rich in Thbearing minerals, the probable provenances of which are the granite and syenite bodies as well as the rare metal and rare earth bearing pegmatites of the region (Santosh 1984; Soman et al 1983). This observation is substantiated by the accessory mineral assemblages in the plutons. Also, the ages reported for monazite $\left(600 \times 10^{6} \mathrm{yr}\right.$; Holmes $1955)$ and zircon $\left(700 \times 10^{6} \mathrm{yr}\right.$; Parthasarathy and Sankardas 1976) from the beach sands are correlatable with the ages of the plutons. Th shows inhomogeneous distribution in each pluton, with large standard deviation (sD) values. Thus, Th levels in Chengannoor show a range of $7-130 \mathrm{ppm}(\mathrm{SD}=42.4$ ), in Ambalavayal from 10 to $41 \mathrm{ppm}(\mathrm{sD}=10.96)$, in Munnar from 6 to $42 \mathrm{ppm}(\mathrm{sD}=17.01)$ and in Peralimala from 3 to $25 \mathrm{ppm}(\mathrm{SD}=6 \cdot 9)$.

\subsection{Uranium}

The mean uranium contents of Chengannoor (10.29 ppm), Ambalavayal $(9.7 \mathrm{ppm})$, Munnar ( $8 \mathrm{ppm})$ and Peralimala $(8.08 \mathrm{ppm})$ are higher than for usual granite ( $4 \mathrm{ppm}$, 


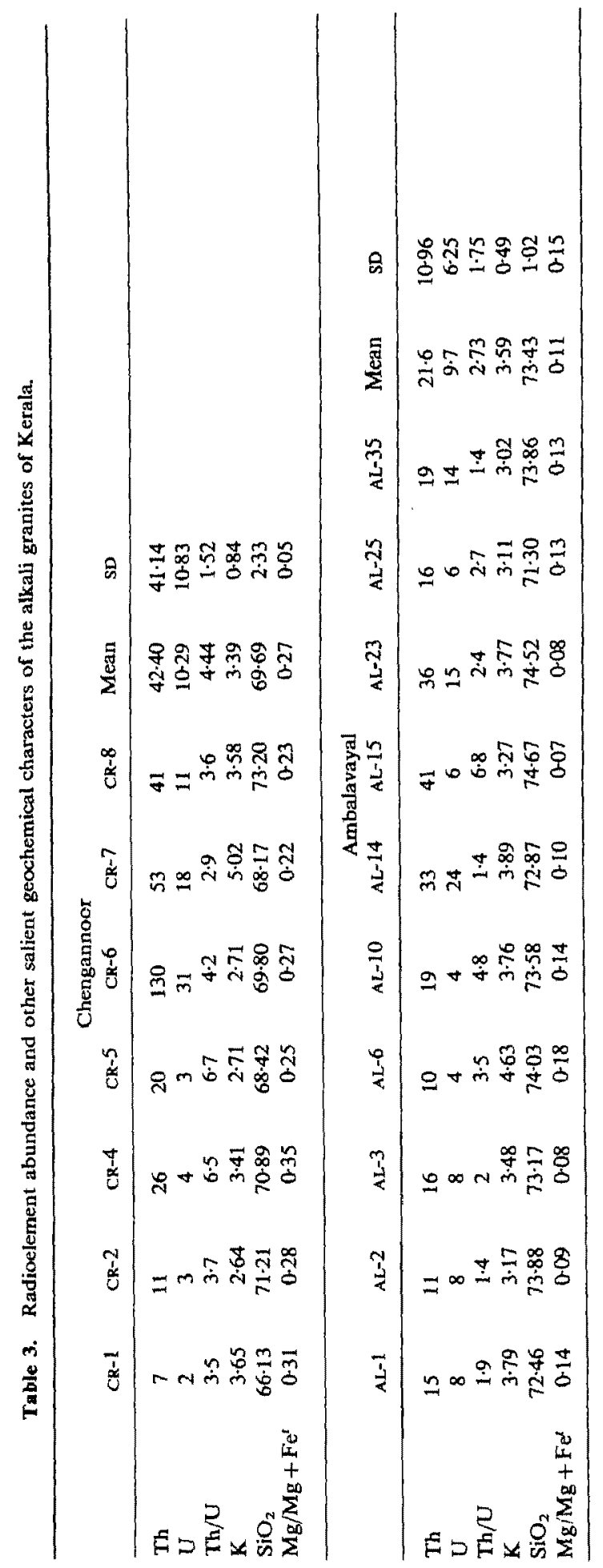




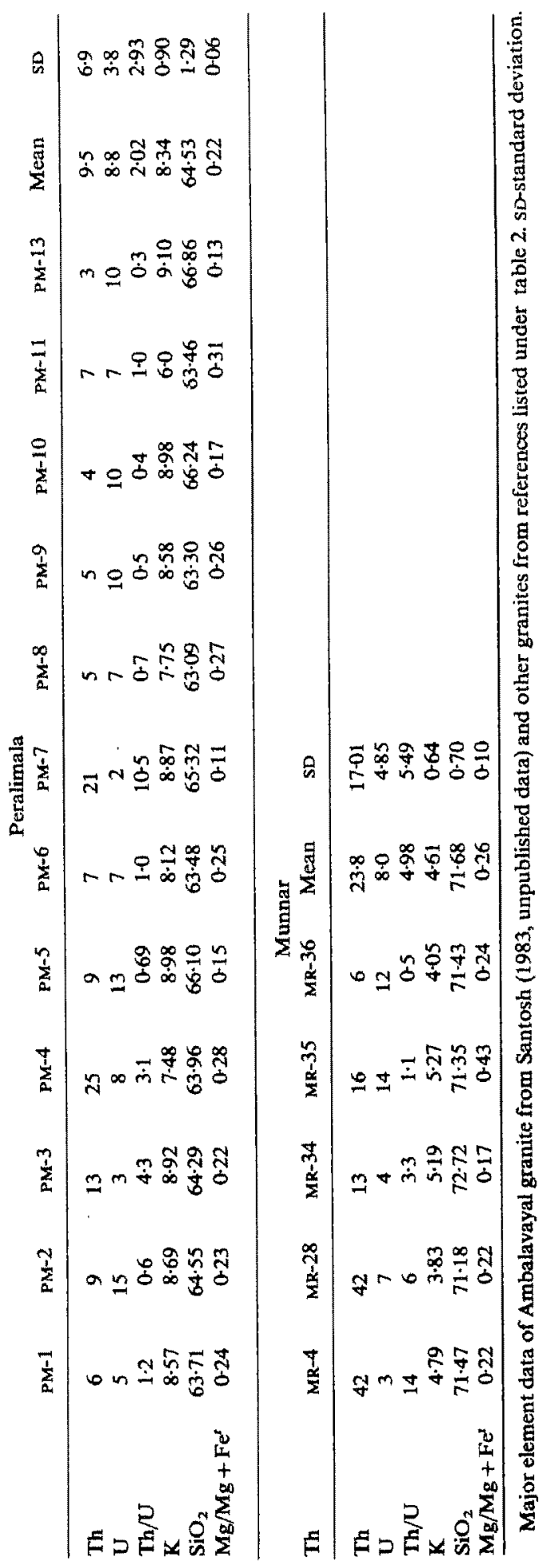


Table 4. Th, $\mathrm{U}$ and $\mathrm{Th} / \mathrm{U}$ values of the alkali granites of Kerala region compared with those from other regions.

\begin{tabular}{lcccccccc}
\hline & CR & AL & MR & PM & P-2 & P-7 & S-6013 & S-6015 \\
\hline Th & 42.40 & 21.60 & 23.80 & 6.90 & 10.0 & 32.0 & 21.20 & 50.0 \\
U & 10.29 & 9.70 & 8.0 & 3.80 & 5.0 & 6.30 & 3.90 & 5.50 \\
Th/U & 4.44 & 2.73 & 4.98 & 2.93 & 2.0 & 5.08 & 5.44 & 9.09 \\
& & & & & & & & \\
\hline & SA & HR & $116 \mathrm{~A}$ & $34 \mathrm{R} / \mathrm{B}$ & $28 \mathrm{~B}$ & NANTB & & \\
\hline Th & 13.0 & 14.0 & 12.0 & 23.0 & 9.0 & 27.0 & & \\
U & 4.0 & 4.0 & 3.0 & 3.0 & 2.0 & 4.0 & & \\
Th/U & 3.25 & 3.50 & 4.0 & 7.67 & 4.5 & 6.75 & & \\
\hline
\end{tabular}

CR-Chengannoor; AL-Ambalavayal; MR-Munnar; PM-Peralimala; P-2 and P7-Chamundi granite (Reddy et al 1983); S-6013 and S-6015-Arsikere granite (Reddy et al 1983); $\$$ A-average of alkali granites of Arabian Shield (Drysdall et al 1984); HRalkali granites of central Hijaz region, Arabia (Jackson et al 1984); 116A, 34 R/B and 28 B-alkali granites of Labrador (Collerson 1982); NANTB- alkali granites of Lleyn Peninsula, North Wales (Croudace 1982).

Rogers and Adams 1969). Wilson and Akerblom (1982) observe that high U contents are characteristic of alkali granites. This is substantiated by the general correlation between $U$ values of the alkali granites with similar granites from other regions (table 4). Uranium also shows inhomogeneous distribution like $T h$, yielding high SD values like 10.83 for Chengannoor and 6.25 for Ambalavayal. In Munnar and Peralimala, the inhomogeneity is less pronounced ( $S D=4.85$ and 3.80 respectively).

\section{$3.3 T h / U$ ratio}

Even though $T h$ and $U$ show wide variation in their distribution (figure 3), the average $\mathrm{Th} / \mathrm{U}$ ratios lie in a limited range of 1.52 to 5.49 , comparable with similar values for alkali granites elsewhere (table 4). The highest variation is exhibited by Munnar with $\mathrm{Th} / \mathrm{U}$ ranging from 0.5 to 14 , whereas Chengannoor shows the least variation (SD $=1.52$ ). In general, alkali granites show higher $\mathrm{Th} / \mathrm{U}$ ratios as compared to normal granites, where the average is only 4 (Rogers and Adams 1969).

\subsection{Potassium}

The average $\mathrm{K}$ contents of Ambalavayal (3.59\%), Munnar (4.6\%) and Peralimala $(8.34 \%)$ are higher than the clarke of $3.6 \%$ for normal granites (Rogers and Adams 1969 ), but comparable with the high $\mathrm{K}$-content of alkali granites in other regions (Rogers and Greenberg 1981). The K-rich nature is a common characteristic of the alkaline plutons in the Kerala region, which, together with the trace element characters suggest magma derivation by partial melting of a $\mathrm{K}$-enriched, $\mathrm{Rb}$-depleted deep crustal 


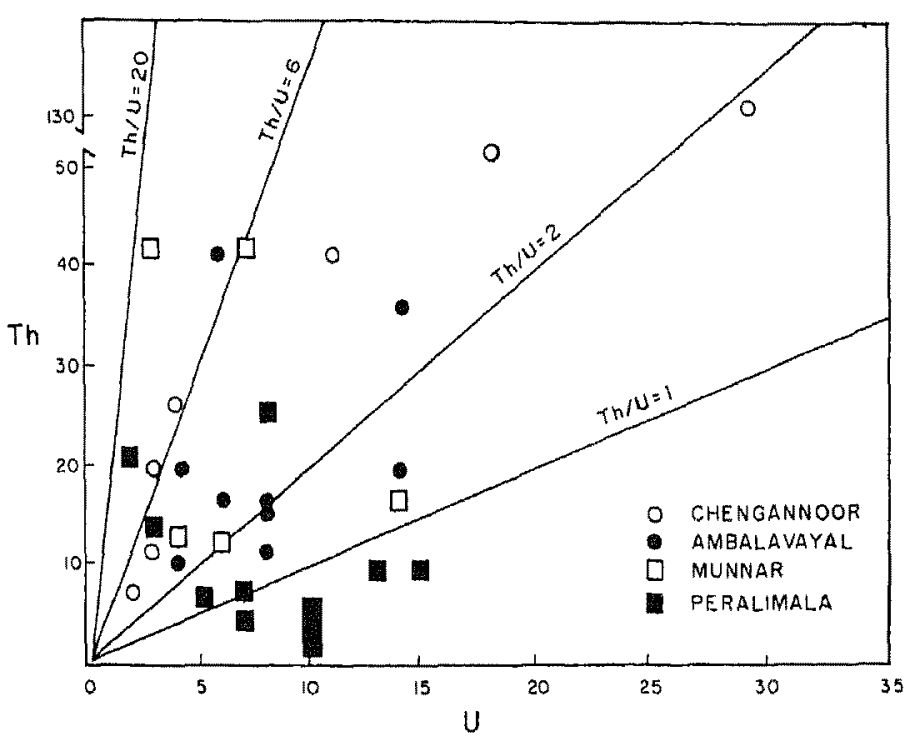

Figure 3. Th vs U plots.

or upper mantle source ( $c f$. Nair and Santosh 1984; Santosh and Thara 1985). There is a consistent homogeneity in the distribution of $\mathrm{K}$ in individual plutons yielding low standard deviation values $(0-49-0.90)$.

\section{Discussion}

Plots of $\mathrm{Th}, \mathrm{U}$ and $\mathrm{Th} / \mathrm{U}$ with respect to $\mathrm{SiO}_{2}$ (figure 4) and $\mathrm{K}$ (figure 5) indicate a poor correlation. Studies by other workers (e.g., O'Conner et al 1982) have also shown weak correlation between $U$ and $T h$ with these major elements. However, plots against $\mathrm{Mg} / \mathrm{Mg}+\mathrm{Fe}^{t}$ indices (figure 6) exhibit definable trends of variation. Th and $\mathrm{U}$ tend to concentrate (except the Th depletion in Munnar) towards lower $\mathrm{Mg} / \mathrm{Mg}+\mathrm{Fe}^{t}$ values, consistent with an enrichment in the radioelement abundance with increasing fractionation. The trends are similar to those obtained by O'Conner et al (1981) for Carrigmore complex. O'Conner et al (1982) observe strong correlation of $U$ and $T h$ with $\mathrm{FeO}$ and $\mathrm{MgO}$. The dependence in the distribution of radioelements with $\mathrm{Mg} / \mathrm{Mg}$ $+\mathrm{Fe}^{t}$ relates to the higher modal content of hornblende, biotite and other accessories in these alkali granites and testifies to the significant role played by ferromagnesium minerals in the fractionation processes ( $c f$. Nair et al 1983). Inter-element correlation and fission-track results presented by various workers (O'Conner et al 1981, 1982) indicate that the radioactive elements are mainly bound in restite accessory phases like zircon, sphene, apatite, allanite and monazite. The ubiquitous occurrence of these accessories in the alkali granites possibly account for the higher levels of Th and U. This is further established by the correlation between the averaged total of accessories and the average abundances of $U$ and $T h$, signifying that the $U$ and $T h$ in these granites are mainly locked up in the accessory minerals. Higher Th-content as compared to $U$ is noted to be a common feature of these granites, yielding high $\mathrm{Th} / \mathrm{U}$ ratios. Rogers et al 
(1978) suggest that there is a preferential release of $U$ relative to $T h$ from the mantle into the derived melt during partial melting. $U$ is released from the mantle not only into the magma but also directly into the volatile phases. Petrochemical and tectonic studies of the alkaline plutons suggest their derivation from partial melts generated in the mantle (Santosh and Thara 1985). An intrinsic association of volatiles with the petrogenesis of these plutons is also suggested (Nair and Santosh 1984). Fluid inclusion studies on the alkaline plutons (Santosh 1985b) and related ore mineralization (Santosh 1984) also indicate that volatiles played a significant role. A taphrogenic control over the generation and emplacement of the alkali granites with the fault-lineaments acting as conduits for volatile transfer from the upper mantle is also deduced (Santosh and Nair 1983b; Santosh 1985b) This together with the common occurrence of Th-bearing
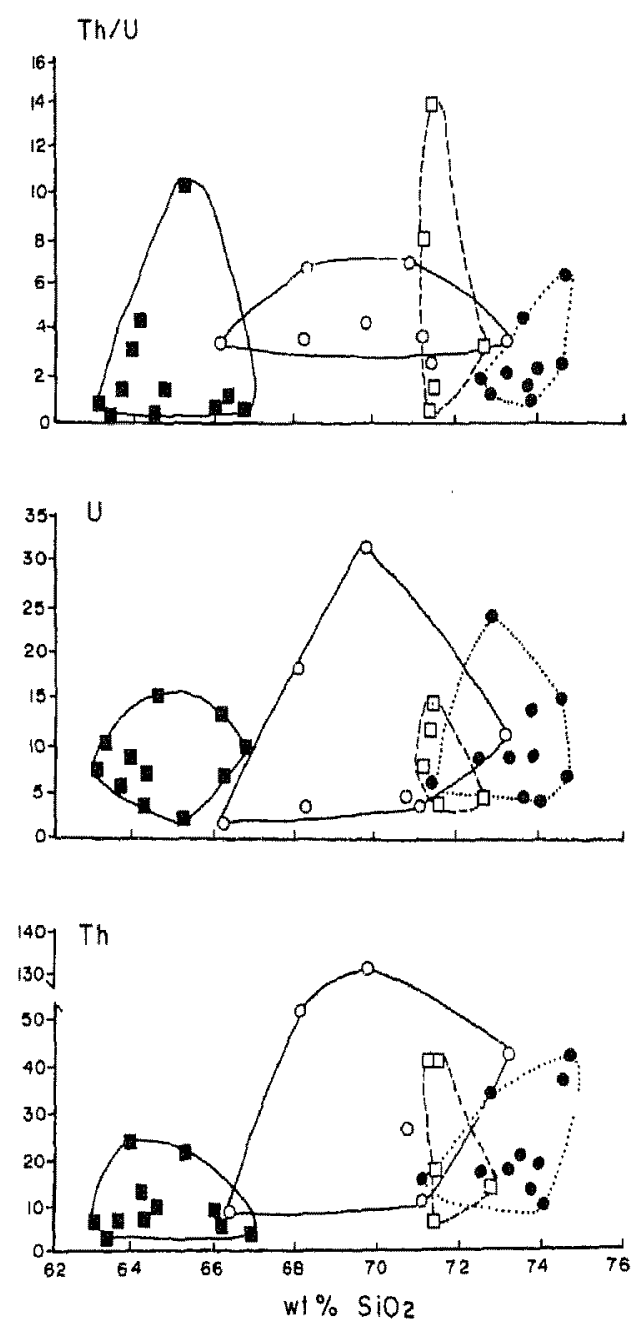

- CHENGANNOOR D MUNNAR

- ambalavayal peralimala

Figure 4. Th, $\mathrm{U}$ and $\mathrm{Th} / \mathrm{U}$ vs $\mathrm{SiO}_{2}$ plots of the alkali granites. 

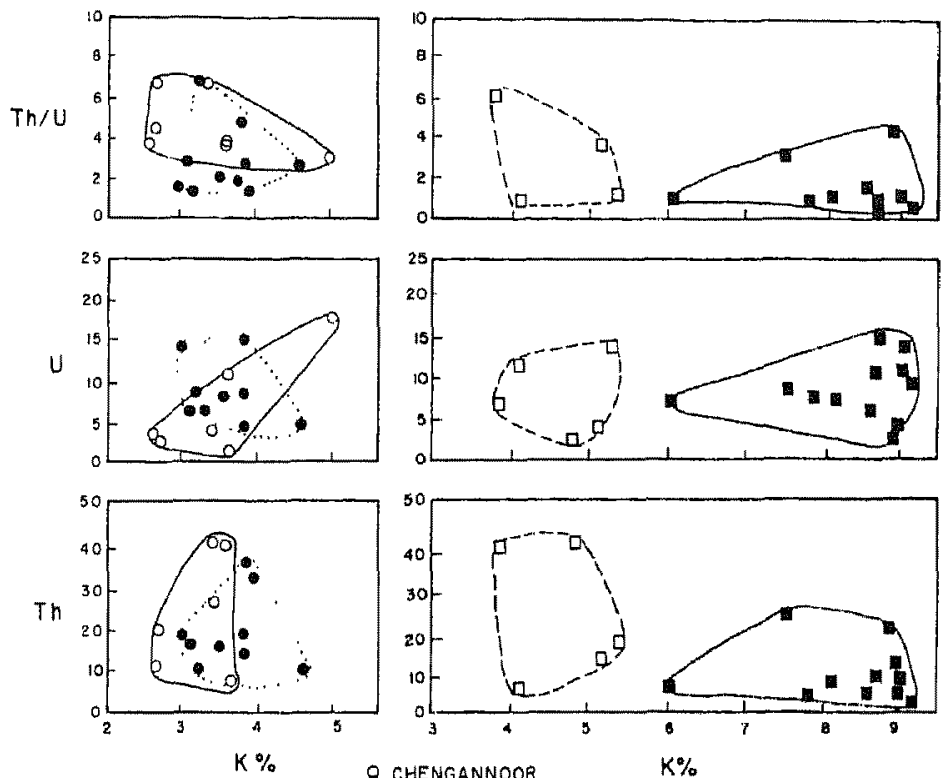

- ambal avayal

d munnar

- peralimala

Figure 5. Th, U and Th/U vs $\mathrm{K}$ plots of the alkali granites.

minerals in the beach placers promise scope for detailed radioelement exploration in the alkali granites. Above all, their similarity to Pan-African alkali granites elsewhere is also significant as investigations have shown that Pan-African provinces are favourable tectonic belts for radioelement mineralization (Ragland and Rogers 1980).

\section{Conclusion}

The alkali granites of the Kerala region show higher Th, $\mathrm{U}$ and $\mathrm{Th} / \mathrm{U}$ contents as compared to normal granites, but are closely comparable with similar alkaline plutons from adjacent terranes and elsewhere. The nature of distribution of radioelements testifies to their correlation with the ferromagnesium minerals and accessory phases. There is a general trend of concentration of $T h$ and $U$ and decrease in $T h / U$ ratio with progressive fractionation. Their Pan-African tectonic setting, alkaline nature and higher Th/U levels, together with the findings of related rare metal pegmatites and the occurrence of Th-rich beach placers in the region are encouraging factors for detailed radioelement exploration in these alkali granites.

\section{Acknowledgements}

The study forms part of a GsD Project on Mineral Exploration. The authors thank the Director, CEss, for encouragement. We are grateful to Dr N G K Nair, for constant encouragement and suggestions. Comments from the referees were helpful in revision of the paper. 

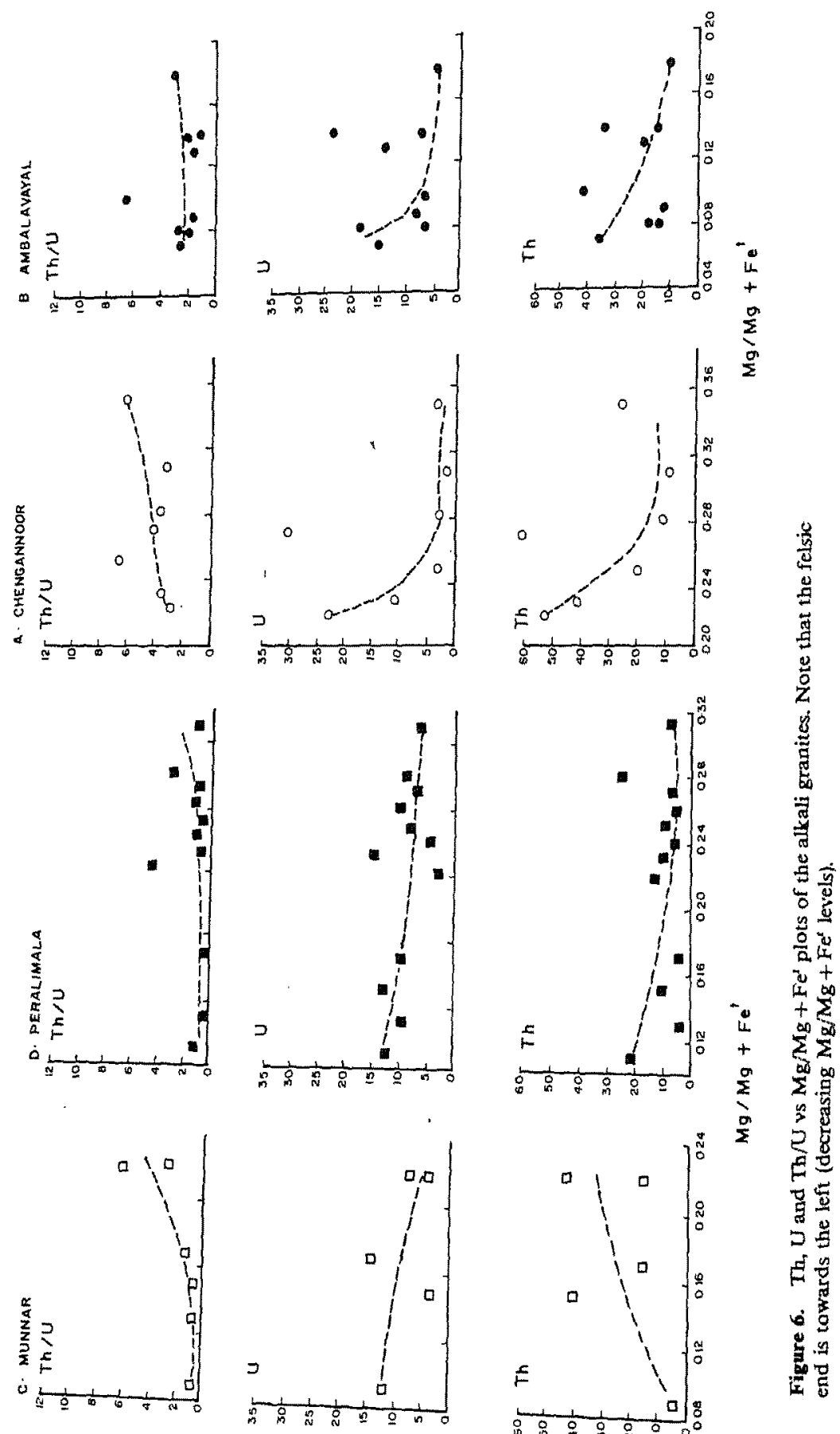


\section{References}

Collerson K D 1982 Contrib. Mineral. Petrol. 81126

Croudace I W 1982 Geochim. Cosmochim. Acta 46609

Drysdall A R, Norman J J, Ramsay C R, Douch C J and Hackett D 1984 Econ, Geol. 791366

Holmes A 1955 Proc. Geol. Assoc. Can. 7342

Jackson N J, Walsh J N and Pegram E 1984 Contrib. Mineral Petrol. 87205

Nair N G K and Santosh M 1984 J. Geol. Soc. India 2535

Nair N G K, Santosh M and Thampi P K 1983 Neues Jahrb. Mineral, Abh. 148223

Nair N G K, Santosh M, Thampi P K and Balasubramonian G 1982 Q. J. Geol. Min. Metal!. Sac. India 5428

O'Conner P J, Reeves T and Hennessy J 1981 Bull. Geol. Surv. Ireland 39

O'Conner P J, Hennessy J, Bruck P M and Williams C T 1982 Geol. Mag. 119581

Odom A L 1982 U N Case No. 81-10084, 10pp

Parthasarathy R and Sankardas M 1976 J. Geol. Soc. India 17262

Ragland P C and Rogers J J W 1980 J. Geochem. Explor. 13181

Reddy G R, Pant D R and Sankardas M 1983 S M Naqvi and J J W Rogers (eds) Geol. Soc. India, Mem. 4329

Rogers J J W and Adams J A S 1969 (ed.) K H Wedepohl in Handbook of geochemistry (Berlin: SpringerVerlag) Vol. II-3, 92-B-1 to $92-0-8$ and $90-\mathrm{B}-1$ to $90-0-5$

Rogers J J W and Greenberg J K 1981 Bull. Geol, Soc. Am. 9257

Rogers J J W, Ragland P C, Nishimori R K, Greenberg J K and Hauck S A 1978 Econ. Geol. 731539

Santosh M 1984 Neues Jahrb Mineral. Monatsh. 6241

Santosh M 1985a J. Geol. Soc. India (in press)

Santosh M 1985b J. Geol. Soc. India 26695

Santosh M and Nair N G K 1983a J. Geol. Soc. India 24291

Santosh M and Nair N G K 1983b Proc. Indian Acad. Sci. (Earth Planet. Sci) 92297

Santosh M, Nair N G K, Pande K and Gopalan K 1985 J. Geol. Soc. India (in press)

Santosh M and Thara K G 1985 Proc. Indian Acad. Sci. (Earth Planet. Sci,) 9443

Soman K, Santosh M and Golubyev V N 1983 Indian J. Earth Sci. 10137

Streckeisen A L 1976 Earth Sci, Rev. 121

Wilson M R and Akerblom G V 1982 Mineral. Mag 46233 